\title{
Randomised placebo-controlled double-blind trial of two dosages of sodium cromoglycate in treatment of varioliform gastritis: comparison with cimetidine
}

\author{
C ANDRÉ, $\dagger$ J GILLON, ${ }^{*}$ B MOULINIER, A MARTIN, AND M C FARGIER \\ From the Unité de Recherche de Physiopathologie Digestive INSERM U 45 et Centre d'Endoscopie \\ Digestive, Pavillon H, Hôpital Edouard Herriot, Lyon, France
}

SUMMARY Eighteen patients with diffuse varioliform gastritis were enrolled in a double-blind, placebo-controlled trial of sodium cromoglycate, $200 \mathrm{mg}$ a day, and sodium cromoglycate, $400 \mathrm{mg}$ a day, for 28 days. An additional six patients were treated with cimetidine $1 \mathrm{~g}$ daily for 28 days. The improvement in terms of patient's subjective assessment, endoscopic assessment, and immunohistochemical measurements of IgE cells in the mucosa was significantly greater in patients given sodium cromoglycate than that in those given cimetidine or placebo. The results provide evidence that type 1 hypersensitivity plays some part in the pathogenesis of varioliform gastritis. It is, therefore, important to differentiate this condition from other types of gastritis, as treatment with sodium cromoglycate appears to be effective.

Diffuse varioliform gastritis is an uncommon form of gastric mucosal inflammation, the incidence in this unit being approximately $0.5 \%$ of over 20000 upper endoscopies. It is an inflammatory condition affecting mainly the body of the stomach, and consists of swollen, congested rugae and scattered erosions situated on discrete mucosal elevations. These 'varioliform' lesions are commonly seen in the antrum, but diffuse varioliform gastritis should only be diagnosed when the mucosa of the fundus and body is affected, the rugae are enlarged, and consistent histological abnormalities are found. Synonyms of this condition include 'octopus sucker gastritis' ${ }^{1}$ and gastritis with complete erosions. ${ }^{2}$

In a review of 90 cases seen in Lyon over a period of eight years, ${ }^{3}$ the clinical features were as follows: epigastric pain $(70 \%$, simulating peptic ulcer in $30 \%$ ), anorexia and nausea with occasional vomiting (31\%), weight loss ( $>5 \mathrm{~kg}$ in $34 \%,>10 \mathrm{~kg}$ in $20 \%$ ), anaemia due to occult blood loss (3.3\%), and overt bleeding (3.3\%). Oedema due to hypoproteinaemia,

\footnotetext{
*Present address: GI Unit and Wolfson Laboratory, Western General Hospital, Edinburgh.

†Address for reprint requests: Dr C André, Hôpital Edouard Herriot, Pavilion $\mathrm{H}^{\mathrm{Bis}}$, 69374 Lyon, Cedex 2, France.

Received for publication 5 August 1981
}

also known to occur in this condition, ${ }^{4}$ was seen in two cases.

In 10 of the 90 patients the lesions occurred acutely after administration of anti-inflammatory drugs (aspirin, indomethacin, phenylbutazone, salazopyrin), but the symptoms were chronic with periods of remission in most patients. Fifty-two patients were followed up for from one to five years. In that time 15 healed spontaneously, 28 improved, eight were unchanged, and one deteriorated. The typical 'varioliform' lesions and hypertrophic gastric folds could be recognised by double-contrast radiology (Fig. 1) or at endoscopy (Fig. 2). Basal and stimulated acid outputs (10 patients) and fasting plasma gastrin (nine patients) were normal.

Histologically the disease is characterised by superficial mucosal ulceration, a chronic inflammatory infiltrate in the lamina propria and enlargement of the gastric glands without loss of specialised cells. The changes seen therefore allow differentiation between this condition and Menetrier's disease, hypertrophic hypersecretory gastropathy, and eosinophilic gastritis, all of which may present similarly, can cause a protein losing state, and may have similar macroscopic appearances.

Histological analysis of the immunoglobulincontaining cell population in the inflammatory 


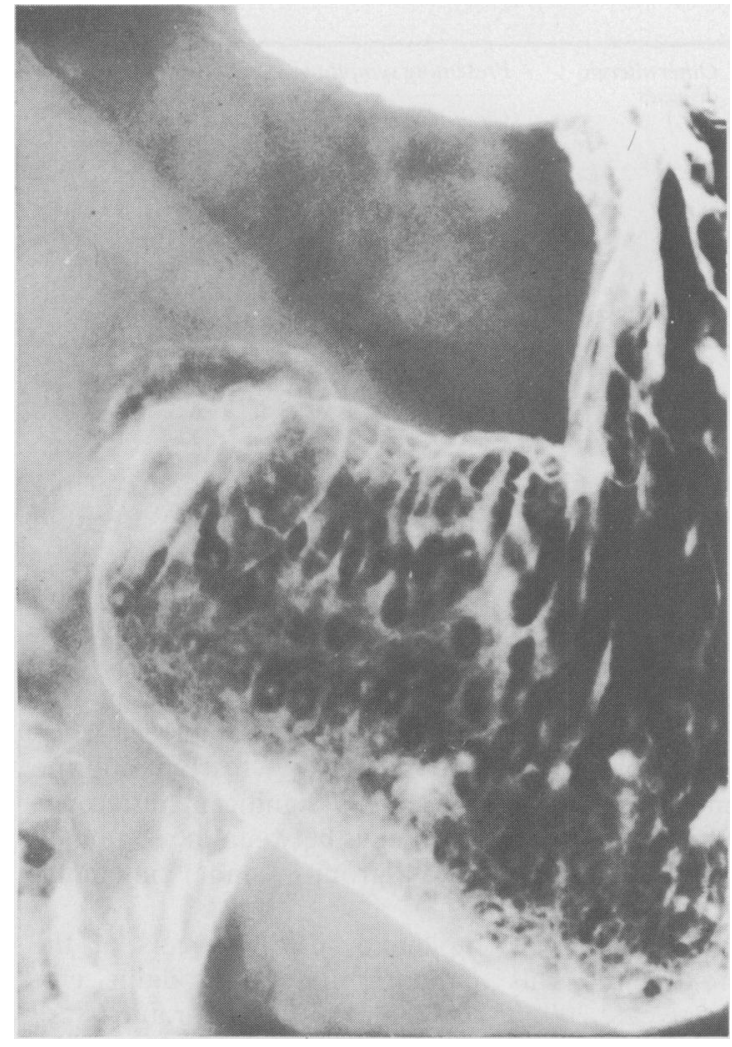

Fig. 1 Double-contrast radiograph showing typical gastric erosions and hyperplastic gastric folds (by courtesy of Professor P Bret, Department of Radiology, Lyon).

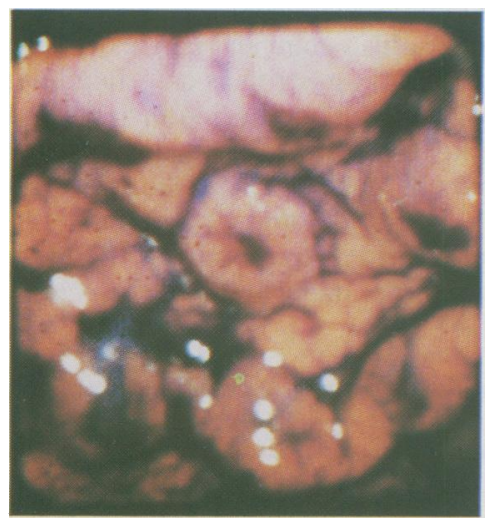

Fig. 2 Endoscopic appearances before treatment showing erosions in the gastric antrum.

infiltrate showed a high proportion of IgE-containing cells. ${ }^{3}$ Raised serum levels of IgE were found in four of 12 patients studied. This suggests that immediate hypersensitivity may be involved in the pathogenesis of the disease, and, encouraged by the results of a pilot study ${ }^{4}$ reported elsewhere, we therefore undertook a randomised, placebo-controlled, double-blind trial of the mast cell stabilising agent sodium cromoglycate (Nalcrom). An uncontrolled comparison with the histamine $\mathrm{H} 2$ receptor antagonist cimetidine (Tagamet) was also made.

\section{Methods}

\section{PATIENTS}

A total of 24 newly presenting patients (17 males, seven females) were studied after the diagnosis of varioliform gastritis had been established endoscopically (Olympus GIF-K endoscope). Biopsies were taken from the fundus and antrum on each occasion for histology and immunohistochemistry. The first 18 patients were randomly allocated to one of three groups: sodium cromoglycate $200 \mathrm{mg}$ or $400 \mathrm{mg}$ daily, or placebo. All three treatments were taken as one ampoule of clear, tasteless liquid before meals and at bedtime for 28 days, the contents of the ampoules being unknown to both the patient and the doctor making the assessments. Six patients were allocated to each group, and the details of the three groups are given in Table 1 . No difference between the groups occurred with respect to age, sex, length of history, or incidence of other allergic diseases. Twelve of the 24 patients described previous allergies: atopic eczema (six patients), asthma (three patients), urticaria (two patients), and one patient had both asthma and eczema. Raised serum levels of $\mathrm{IgE}$ were found in 10 subjects (range 266-1700 $\mu \mathrm{g} / \mathrm{l}$, normal range $<250 \mu \mathrm{g} / \mathrm{l}$ ), and these patients were evenly distributed throughout the three groups. Eosinophilia was observed in six patients, no difference being observed between the respective groups.

An additional six patients were treated with cimetidine $1 \mathrm{~g}$ daily for 28 days, no attempt being made to 'blind' this part of the study.

Clinical and endoscopic assessment including biopsies were made immediately before and after the treatment period, and patients were asked to rate the result as complete cure, considerable improvement, or failure. A similar rating systems was used by the endoscopist.

Immunohistochemical measurements of the numbers of plasma cells of each immunoglobulin class were made using a previously described method. ${ }^{5}$ Fragments of gastric tissue were fixed in $96 \%$ ethanol for 24 hours at $4^{\circ} \mathrm{C}$, after a 24 hour incubation in cold phosphate buffered saline $(0.01 \mathrm{M}$ phosphate, $\mathrm{pH}$ $7 \cdot 2,0.13 \mathrm{M} \mathrm{NaCl}$ ) to reduce background by washing out interstitial proteins. Serial sections of $4 \mu \mathrm{m}$ were cut after being embedded in paraffin. Intracellular 
Table 1 Clinical features of four treatment groups

\begin{tabular}{|c|c|c|c|c|c|c|c|}
\hline \multirow[t]{2}{*}{ Group } & \multirow[t]{2}{*}{ No. } & \multirow{2}{*}{$\begin{array}{l}\text { Mean age } \\
(y r)\end{array}$} & \multirow{2}{*}{$\begin{array}{l}\text { Raised serum IgE } \\
\text { (no.) }\end{array}$} & \multirow{2}{*}{$\begin{array}{l}\text { Other allergic } \\
\text { diseases } \\
\text { (no.) }\end{array}$} & \multicolumn{3}{|c|}{ Presentingsymptoms } \\
\hline & & & & & $\begin{array}{l}\text { Ulcer-type } \\
\text { dyspepsia }\end{array}$ & $\begin{array}{l}\text { Nonspecific } \\
\text { dyspepsia }\end{array}$ & $\begin{array}{l}\text { Anorexia } \\
\text { weight loss }\end{array}$ \\
\hline \multicolumn{8}{|l|}{ Cromoglycate } \\
\hline $200 \mathrm{mg} / \mathrm{day}$ & 6 & 55 & 2 & 3 & 2 & 2 & 2 \\
\hline $400 \mathrm{mg} / \mathrm{day}$ & 6 & 55 & 4 & 3 & 1 & 2 & 3 \\
\hline Placebo & 6 & 54 & 2 & 3 & 2 & 1 & 3 \\
\hline \multicolumn{8}{|l|}{ Cimetidine } \\
\hline $1 \mathrm{~g} /$ day & 6 & 52 & 2 & 3 & 2 & 2 & 2 \\
\hline
\end{tabular}

staining was performed in one step, five adjacent sections being used for each of the immunoglobulin classes. Rabbit anti-human immunoglobulin A, M, $\mathrm{G}, \mathrm{D}$, and $\mathrm{E}$ antisera were purchased (Behringwerke A.G. Germany) as fluorescein conjugates and were used as whole sera diluted 1:20. The specificity of the antisera was assessed by immunoelectrophoresis against plasma proteins. In particular, the specificity of the anti-epsilon heavy chain antiserum was verified by immunoelectrophoresis and Ouchterlony double immunodiffusion against a myeloma IgE protein (kindly furnished by Dr J P Vaerman, Institut de Pathologie Cellulaire, Département de Médecine Expérimentale, Université de Louvain, Belgium). Fluorescence microscopy was performed using a Leitz Orthoplan microscope equipped with a Ploemtype vertical illuminator. The number of fluorescent cells in each immunoglobulin class was obtained by counting the fluorescent cells in three adjacent 'tissue units'-that is, the entire lamina propria area between muscularis mucosae and surface epithelium over a length of $0.24 \mathrm{~mm}$ per unit - and taking the arithmetical mean. The total number of Igcontaining cells for each specimen was derived by adding the numbers from each Ig class. This method is an adaptation of that described by Brandtzaeg et al. ${ }^{6}$

Control immunohistochemical studies were performed using comparable biopsies from 25 subjects having macroscopically and histologically normal gastric mucosa.

\section{Results}

The patient's and endoscopist's assessments of the efficacy of treatment are shown in Table 2. Because of the small numbers involved no superiority over placebo or cimetidine can be demonstrated statistically for the two individual sodium cromoglycate groups, but if these two groups are combined a clear superiority over both cimetidine and placebo can be demonstrated for the patient's subjective assessment $\left(\mathrm{P}<0 \cdot 04, \chi^{2}\right.$ test $)$. Using the endoscopist's rating the only significant difference which can be demonstrated is between the combined sodium cromoglycate groups and cimetidine $\left(\mathrm{P}<0.04, \chi^{2}\right.$ test $)$.

One patient complained of side-effects of the treatment. This patient receiving sodium cromoglycate $200 \mathrm{mg}$ daily felt that her migraines were exacerbated by the treatment, but did not have to be withdrawn from the study. Another patient in the same group reported that his eczema, for which he had been receiving treatment unsuccessfully for one year, was completely cured.

The immunohistochemical studies confirmed that diffuse varioliform gastritis is associated with an increase in plasma cell numbers both in the antrum and in the fundus. The effects of the different regimes on the numbers of plasma cells of the various Ig classes are shown in Tables 3 and 4. Comparison of all the patients with varioliform gastritis with the 25 controls reveals an increase in the number of IgA plasma cells,

Table 2 Patient's and endoscopist's assessments of results of treatment with sodium cromoglycate $200 \mathrm{mg}$ or $400 \mathrm{mg}$ daily, cimetidine $1 \mathrm{~g}$ daily, or placebo

\begin{tabular}{|c|c|c|c|c|c|c|}
\hline \multirow[t]{2}{*}{ Treatment group } & \multicolumn{2}{|c|}{ Patient's rating } & \multirow[b]{2}{*}{ Failure } & \multicolumn{2}{|c|}{ Endoscopist's rating } & \multirow[b]{2}{*}{ Failure } \\
\hline & Cure & $\begin{array}{l}\text { Considerable } \\
\text { improvernent }\end{array}$ & & Cure & $\begin{array}{l}\text { Considerable } \\
\text { improvement }\end{array}$ & \\
\hline \multicolumn{7}{|l|}{ Cromoglycate } \\
\hline $200 \mathrm{mg} / \mathrm{day}$ & 2 & 3 & 1 & 3 & 2 & 1 \\
\hline $400 \mathrm{mg} / \mathrm{day}$ & 5 & 1 & () & 2 & 4 & 0 \\
\hline Placebo & 1 & 1 & 4 & 0 & 4 & 2 \\
\hline $1 \mathrm{~g} /$ day & 2 & 0 & 4 & 2 & 0 & 4 \\
\hline
\end{tabular}


Table 3 Average numbers of Ig-containing cells in three tissue units of gastric antrum

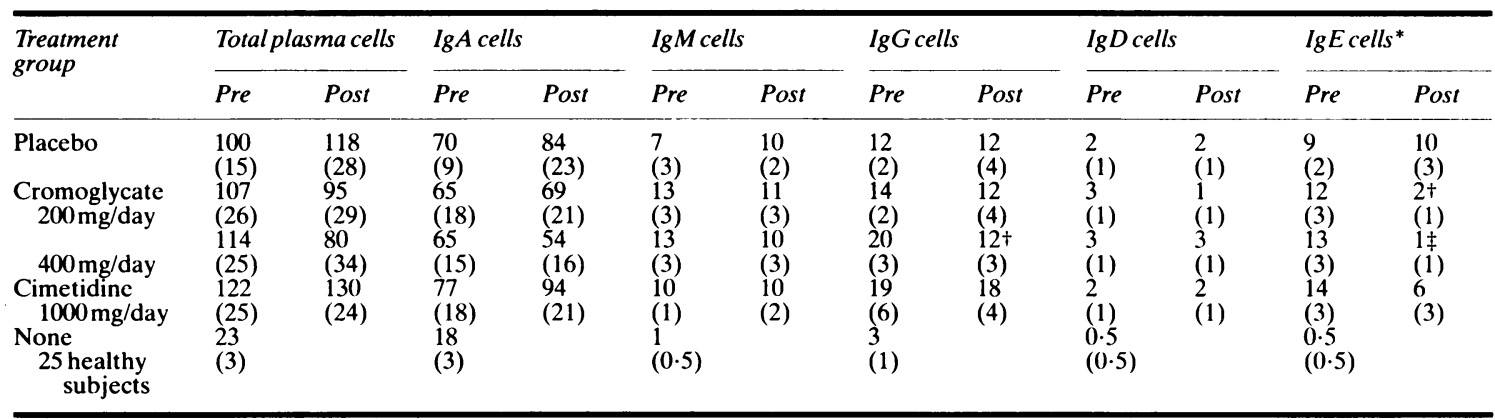

* Plasma cells and/or activated mast cells.

$+\mathrm{P}<0.05$.

$\ddagger \mathrm{P}<0 \cdot 01$.

Figures in parentheses represent SEM

Pre: pre-treatment.

Post: post-treatment.

Table 4 Average numbers of Ig-containing cells in three tissue units of gastric fundus

\begin{tabular}{|c|c|c|c|c|c|c|c|c|c|c|c|c|}
\hline \multirow{2}{*}{$\begin{array}{l}\text { Treatment } \\
\text { group }\end{array}$} & \multicolumn{2}{|c|}{ Total plasma cells } & \multicolumn{2}{|c|}{ IgA cells } & \multicolumn{2}{|c|}{ IgMcells } & \multicolumn{2}{|c|}{ IgG cells } & \multicolumn{2}{|c|}{ IgD cells } & \multicolumn{2}{|c|}{$\operatorname{IgE}$ cells $^{*}$} \\
\hline & Pre & Post & Pre & Post & Pre & Post & Pre & Post & Pre & Post & Pre & Post \\
\hline
\end{tabular}

* Plasma cells and/or activated mast cells

$+\mathrm{P}<0.05$.

$\ddagger \mathrm{P}<0 \cdot 01$.

Figures in parentheses represent SEM.

Pre: pre-treatment.

Post: post-treatment

slight increases in IgG, IgM and IgD cell numbers, and a marked increase in cells containing $\operatorname{IgE}$ $(\mathrm{P}<0.001$, Student's $t$ test for unpaired data). Differentiation between IgE plasma cells and activated mast cells was not possible.

Treatment with placebo produced no change in either total or Ig class-specific plasma cell numbers. Sodium cromoglycate $200 \mathrm{mg}$ daily resulted in a significant change in $\mathrm{IgE}$ cell numbers in the fundus $(\mathrm{P}<0.05)$ and in the antrum $(\mathrm{P}<0.05)$. Sodium cromoglycate $400 \mathrm{mg}$ daily also produced a significant fall in $\mathrm{IgE}$ cell numbers in both antrum and fundus $(P<0.01)$ and a significant fall in IgG cells in the antrum $(P<0 \cdot 05)$, while the effects of cimetidine were not significant (all statistics performed using Student's $t$ test for paired data).

\section{Discussion}

Previous studies of diffuse varioliform gastritis have provided compelling evidence that the disease may have an allergic basis, or at least that type 1 hypersensitivity plays some part in the pathogenesis of the disease. ${ }^{3}{ }^{4}$ No specific allergens have, as yet, been identified, but the allergic nature of the disease is suggested by the typical relapsing clinical course, the increased incidence of other allergic diseases in these patients as compared with the normal population, the high incidence of eosinophilia and raised serum IgE levels, and finally the demonstration of large numbers of IgE-containing cells in the gastric mucosa. The results of the present study lend additional support to this argument, treatment with sodium cro- 
moglycate having shown a clear advantage over placebo and cimetidine. This clinical improvement appeared to correlate with a return to normal values of the distribution of Ig class-specific plasma cell in the mucosa, and particularly with a fall in IgEcontaining cell numbers to normal levels. Sodium cromoglycate $200 \mathrm{mg}$ daily seemed to be as effective as the larger dose of $400 \mathrm{mg}$ daily. Treatment was given in liquid form before meals on the presumption that any allergenic substances would most likely be ingested during the course of a meal. The open study using cimetidine indicated that any beneficial effect of this agent is likely to be minimal.

Sodium cromoglycate is well established as being effective in the treatment of bronchial asthma, but its use in other allergic diseases is limited by the fact that it is not absorbed when taken orally. Nevertheless, it has been used in several studies of inflammatory bowel disease on the basis that increased numbers of eosinophils and mast cells are sometimes seen in the colonic mucosa of such patients. The results of such studies have been variable and, on the whole, disappointing. ${ }^{78}$ but there seems little doubt that occasional patients benefit dramatically, indicating that oral sodium cromoglycate can be effective even though it is not absorbed. Taken with the results of our own study this may indicate that this compound could be useful in other gastrointestinal diseases characterised by the presence of $\operatorname{IgE}$ cells or mast cells in the mucosa-for example, peptic ulceration. ${ }^{9} 10$

Sodium cromoglycate acts by blocking the release of the mediators of inflammation, principally histamine, serotonin, and SRS-A, released by mast cells coated with $\mathrm{IgE}$ on appropriate antigenic challenge. Cell kinetic studies suggest that it may be the effect of excessive histamine release which gives rise to the gastric gland hyperplasia that is the characteristic histological abnormality seen in varioliform gastritis. "Histamine and the other mediators of immediate hypersensitivity also produce changes in mucosal permeability to macromolecules, and the efficacy of sodium cromoglycate might therefore reside in its ability to interrupt the vicious circle of macromolecule (allergen) absorption, sensitisation, mediator release, and further macromolecule absorption. ${ }^{12}$ Furthermore, the interruption of allergen absorption would explain why one of our patients noted a remarkable improvement in his eczema while receiving treatment with cromoglycate.

We are indebted to Fisons Pharmaceuticals Ltd for supplying the active preparations of sodium cromoglycate, and the placebo.

\section{References}

1 Tsuneoka K, Takemoto T, Fukuchi S. Fiberoscopy of gastric diseases. Stuttgart: Fischer Verlag, 1973.

2 Von Soehendra N, Rehner M, Sternberg N, et al. Die chronischen (kompletten) Erosionen des Magens. Munch Med Wschr 1972; 114: 1857-60.

3 Lambert R, André C, Moulinier B, et al. Diffuse varioliform gastritis. Digestion 1978; 17: 159-67.

4 André C, Moulinier B, Lambert R, et al. Gastritis varioliformis, allergy and disodium cromoglycate. Lancet 1976; 1: 964-5.

5 André C, Lambert R, Fargier MC. Étude endoscopique, histologique et immunohistochimique en doubleaveugle de l'influence thérapeutique de l'amixetrine dans les antrites. Biol Gastroenterol (Paris) 1976; 9: 283-8.

6 Brandtzaeg P, Baklien K, Fausa O, et al. Immunohistochemical characterization of local immunoglobulin formation in ulcerative colitis. Gastroenterology 1974; 66: $1123-36$.

7 Cella GD, Garibaldi LR, Durand P. Ulcerative colitis and disodium cromoglycate. Lancet 1976; 1: 1129.

8 Heatley RV, Calcraft BJ, Rhodes J, et al. Disodium cromoglycate in the treatment of chronic proctitis. Gut 1975; 16: 559-63.

9 Brown WR, Borthistle KB, Chen ST. Immunoglobulin $\mathrm{E}(\mathrm{IgE})$ and $\mathrm{IgE}$-containing cells in human gastrointestinal fluids and tissues. Clin Exp Immunol 1975; 20: 227-37.

10 André F. André C, Vialard JL. Role of homocytotropic antibodies in peptic ulcer pathogenesis in humans and animals. Drugs Exp Clin Res 1979; 5: 19-25.

11 André F, André C, Fournier S. Measurement of glycoprotein content and cell kinetics in preulcerous gastric mucosa. Dig Dis Sci 1979; 24: 667-71.

12 Paganelli R, Levinsky RJ, Brostoff J, et al. Immune complexes containing food proteins in normal and atopic subjects after oral challenge and effect of sodium cromoglycate on antigen absorption. Lancet 1979; 1 : $1270-2$. 